\title{
Questioning the concept of culture in mainstream occupational therapy
}

\author{
Vagner dos Santos ${ }^{a}$, Sara Leon Spesny ${ }^{b}$ \\ aFaculdade de Ceilândia, Universidade de Brasília - UnB, Brasília, DF, Brazil. \\ ${ }^{\mathrm{b}}$ Institut de Recherche Interdisciplinaire sur les Enjeux Sociaux, Ecole des \\ Hautes Études en Sciences Sociales, France.
}

\begin{abstract}
It has been about 25 years since the concepts of culture and diversity were included in the theoretical sight of occupational therapy. Once a matter of anthropological discussion, occupational therapy recognized the value of thinking about culture and the diverse forms of human presence in the world. In this sense, occupational therapy has dawned from anthropology its cultural 'curiosity'. Thus, in this essay we aim to contextualize what we call mainstream occupational therapy and its use of culture. We did not focus over any theoretical or practical models, but rather on shared views of this concept at the international level. This is followed by a reflection upon this concept from an anthropological perspective, that avoids culturalist explanations. Finally we argue for an epistemological use of culture within occupational therapy. Throughout this essay we also drive a critical reflection of the influence of the Global North values within occupational therapy's implementation and development in the Global South.
\end{abstract}

Keywords: Occupational Therapy, Anthropology, Culture, Epistemology.

\section{Questionando o conceito de cultura nas linhas de terapia ocupacional domintantes}

Resumo: Há, aproximadamente, 25 anos desde que os conceitos de cultura e diversidade foram incluídos nas discussões teóricas de terapia ocupacional. Uma vez temas de discussão antropológica, a terapia ocupacional reconheceu o valor de pensar sobre a cultura e as várias formas de presença humana no mundo. Neste sentido, a terapia ocupacional despertou, assim como a antropologia, uma "curiosidade" sobre o conceito de cultura. O objetivo deste ensaio é contextualizar o que nomeamos como terapia ocupacional dominante e seus usos do conceito de cultura. Embora, não tenhamos focado em nenhum modelo teórico específico, tentamos entender as visões sobre o conceito de cultura compartilhadas no âmbito internacional. O ensaio segue com uma reflexão sobre a perspectiva antropológica do conceito de cultura, que evita a produção de explicações culturalistas. Finalmente, apresenta-se a possibilidade do uso de cultura nas discussões epistemológicas da terapia ocupacional. Adicionalmente, ao longo do texto realizamos um reflexão crítica sobre a influência de valores da terapia ocupacional de países do chamado Norte Global em sua implementação e desenvolvimento em países do Sul Global.

Palavras-chave: Terapia Ocupacional, Antropologia, Cultura, Epistemologia.

Corresponding author: Vagner dos Santos, Faculdade Ceilândia, Universidade de Brasília, Centro Metropolitano, conjunto A, lote 1, CEP 72220-900, Brasília, DF, Brazil, e-mail: vagner@unb.br

Received on May 28, 2015; $1^{\text {st }}$ Revision on Nov. 10, 2015; Accepted on Dec. 1, 2015. 


\section{Introduction}

It has been about 25 years since the concepts of culture and diversity were included in the theoretical sight of occupational therapy (KINÉBANIAN; STOMPH, 2010). Once a matter of anthropological discussion, occupational therapy recognized the value of thinking about culture and the diverse forms of human presence in the world. In this sense, occupational therapy has dawned from anthropology its cultural "curiosity". The flipside of the discussion about culture is that it can also lead to culturalist explanations of diversity, in which essentializing differences, historical and political perspectives are left aside the reflection.

In this sense, a self-reflective exercise may put forward new shifts in meaning and practice. Indeed challenging some of the premises of what we call "mainstream" occupational therapy we highlight new possible configurations of the field, as differences are recognized between the Global North and the Global South¹.

It is at the crossroad of these fields that we can shed a better understanding about possible routes to follow. This is not to say that there are not a handful of occupational therapist that have had combined knowledge from anthropology and occupational therapy to move forward in this discussion (FRANK; BLOCK; ZEMKE, 2008). This also reveals the closeness of the fields and the potentialities of the discussion.

We draw this discussion from the dialogue between research and practice as an occupational therapist and an anthropologist. It is within the views and reflections of each field that we propose to take a step back and look at the usages of "culture" and -avoiding any quick solutions or propositions- we seek to challenge and question some of these conceptualizations pointing towards an epistemological utility of "culture" within occupational therapy. In this sense, we aim to contextualize what we call mainstream occupational therapy and its use of culture.

\section{Mainstream Occupational Therapy: a short overview}

According to Frank and Zemke (2008) occupational therapy had a dynamic origin in the United States of America. This story recalls a political and societal involvement of occupational therapy in its early days that was lost by the time of the First World War when "[...] the profession was formally organized, bureaucratized and medicalized" (FRANK; ZEMKE,
2008, p. 130). These processes in one hand placed occupational therapy under the scope of medical professions. On the other hand, left aside occupational therapy's interest in political, social and cultural dimensions of its epistemology and practice.

The industrial and economic growth experienced during the last century in the Global North, especially in the United States, drove occupational therapy into the industrial and the American middle class values. Consequently occupational therapy defined its practices based on norms defined by these western values. Indeed, Trentham et al. (2007, p. S51) summarize that

[...] occupational therapy culture has been largely defined and perhaps dominated by female, Western, middle-class and heterosexual perspectives.

The focus over the body and defined worldviews of daily life dictate occupational therapy interventions and theories during most of the $20^{\text {th }}$ century. Here there was not much room for diversity, nor for what people or communities needed or wanted to do, instead an increasing normalization of what was expected to be done was promoted, i.e. mainly being able to mass produce and mass consume.

This industrialization process, as remarked by Gusfield (1996), created time-frame societies. For him, contemporary industrialized societies are time-bounded. For instance, the use of weekend as a contrast to the week implies a routinized scheduling of time in which a period of work and a period of play exist as a contrast, when the weekend becomes a release from rules and the tasks of daily routine. Thus, in this framework and daily life scheme that mainstream occupational therapy developed and arranged its therapeutic goals to promote independence and an intervention based on what Gusfield (1996) called the benevolent-repression-orientated toward those defined as pathological, abnormal or deviant.

This rationale of one's "independence" was allocated into the rehabilitation process. Thus, independence for activities of everyday life becomes the central focus of treatment offered by occupational therapist throughout the $20^{\text {th }}$ century. Even if individual rehabilitation practice has developed and supported the scientific legitimacy of occupational therapy in some extend, it is worth to critically reflect upon the range of activities and life styles that has been considered legitimate in the field. The worldwide economic system imposed by the Global North focused on the individual economical independence as the final goal of the human project influenced the roots of occupational therapy. Consequently, the 
field is a social construction shaped by capitalism and neoliberalism. And as we will focus in the next section, it's more recent turn - which includes a western reflection over diversity and culture- still has much of its historical origins and goals.

\section{Culture and diversity in mainstream occupational therapy}

Recent intersections between anthropology and occupational therapy have their roots mainly with the discussion of the concepts of culture and diversity. Traditionally constructed and formulated by anthropology, these two concepts and their implication within occupational therapy practice have been discussed over the last two decades or so in mainstream occupational therapy literature. There is however, still discrepancy regarding meanings and definitions, as well as towards "were to go" with these concepts. They have been mainly discussed to improve services and make a relevant practice. According to Kinébanian and Stomph (2010) the issues of Culture and diversity were first discussed at the international level in 1990 at the World Federation of Occupational Therapists (WFOT) Congress in Australia and ten years later the document "Diversity matters: Guiding Principles on Diversity and Culture" was presented at the 2010 WFOT Congress in Chile.

On one hand, this document established a definition of culture based on Helman (2007) who himself relies on Edward Burnett Tylor's classic 1871 definition (TYLOR, 1871). To Tylor's "[...] complex whole which includes knowledge, beliefs, morals, law, customs and any other capabilities and habits acquired by men as a member of society" (Tylor, 1871, s.n. apud Kinébanian and Stomph, 2010, p. 6). Helman adds that "[...] culture comprises systems of shared ideas, systems of concepts and rules and meanings that underlie and are expressed in the ways that human beings live" (HELMAN, 2007 apud KINÉBANIAN; STOMPH, 2010, p. 6). Additionally, diversity refers to

[...] the pluriformity in which humankind presents itself, such as ethnicity, culture, socio-economic position, caste, gender, class, sexual identity, age and religious beliefs (KINÉBANIAN; STOMPH, 2010, p. 6).

On the other hand, Fitzgerald points out that culture and diversity are not to be used as synonyms, instead -assuming that culture is "slippery" to define- she states that "[...] culture is learned, shared, patterned ways of perceiving and adapting to the world around us (our environment) that is characteristic of a population or society" (FITZGERALD, 2004, p. 494).

On a similar note, Watson's definition refers to the

[...] expressions to the norms, values and beliefs of each group and fostered the cultivation of its imagination, skills, traditional knowledge and resources, and ultimately its heritage and worldviews. [...] it is about the future and about aspirations and opportunity as much as about constraints, how people view themselves, how they view others in respect to themselves and how others view them. Culture is about power relationships and what produces power (WATSON, 2006, p. 152).

Without exhausting the definitions that occupational therapists have given to the concepts of culture and diversity through the last decades, we have sketched an overview of some of these notions that has been presented at the international level. Here, definitions of culture presented above include a dynamic, "all-encompassing" notion, in which ideas and values create a web of meanings and behavior patterns that shape the individual but are common and transmitted collectively, forming a shared social world. These conceptualizations have also been established by anthropologists themselves revealing a clear junction between the fields.

They are also the result of mainstream occupational therapy's encounter with "the other"- mainly migration and other "minorities" - that have demanded certain adaptations of its practice. However, as we will explore in the next section, the concepts of culture and diversity within anthropology have also been a historical source of debate in which culturist explanations are also a danger to critical thought.

\section{Questioning the concepts of culture and diversity from an anthropological perspective}

Anthropology certainly has led the discussion of culture and notions associated to it. Indeed, the discipline has been largely developed around the concept of culture and has notably established the discussion of its modern meaning. However, even if anthropology has grown around this core concept, it has also been the ground for discussions, contestations and debates. Always elusive, the concept of culture has refused to remain a consensus among anthropologists.

From Tylor's first formal anthropological conceptualization in the late $19^{\text {th }}$ century, the concept 
of "culture" has had different perspectives shaping it's meaning. Lewis Morgan's evolutionary ideas (that contrasted civilization and primitive societies that "evolved" into complex systems) gave way to Frantz Boas's historical particularism (in which each society developed it's culture in incommensurable ways). Boas's cultural relativist ideas were followed with functionalists and structural-functionalists approaches, such as those presented by Malinowski and Radcliffe-Brown that gave way for instance, to Levi-Strauss's definition as the intersection of the biological and the societal. More recently, Symbolism has also been part of the anthropological discussion, leading for instance to Clifford Geertz's culture concept relaying on semiotics.

This brief condensation of the historical turns of the concept of culture - that again is not at all exhaustive - illustrates the radically different conceptualizations that have marked the discipline. They have, however, also been western- and contrary to occupational therapy, male - constructions and views of the world that came about with the encounter of "the other".

Indeed, the conceptualization of culture and diversity within anthropology has also led to culturalist explanations of the world. Here, for instance, poverty, inequality and power relations can be acknowledged but are not questioned. These culturalist views of the world are based on rooted stereotypes and shared ideas regarding certain populations.

This process of "othering" based on cultural presumptions can lead to the incorporation of the notion of culture and diversity in a superficial way within occupation therapy. Culturalist explanations have been questioned by critical anthropology. For instance, Didier Fassin (2006) when studying HIV in South Africa reveals that culture and cultural behaviors were often mobilized to explained black population's higher rates of contagion. For him, culturalism "essencializes the difference" and produces an a-historical view in which, in this case, gave culture a predominant role that explained the rapid contagion rates in black population and the failure of prevention campaigns and treatments.

Indeed, culturalist views and explanations regarding health, behavior and treatment, specifically within occupational therapy as an applied science delivering care, are a danger for the critical thought in the field. This pragmatist heritage of occupational therapy has already been questioned within occupational therapy (FRANK; BAUM; LAW, 2010; GALHEIGO, 1988).

Long have been the days of Tylor's definition of culture, the first in the discipline. New conceptualizations and reflections are coming to the forefront of the discipline. Along with a continuous debate within anthropology to pinpoint a definition for culture, a shift towards other perspectives merits some attention. Subjectivity (BIEHL; GOOD; KLEINMAN, 2007), structural violence (FARMER, 1996), biopolitics (FOUCAULT, 2010), cultural capital (BOURDIEU, 1986) to mention few, could become promising themes to be discussed within occupational therapy.

Over the past decades, within mainstream occupational therapy there have been constant efforts to recognize culture and diversity, both that incorporate the relevance of health disparities and poverty, exclusion and inequalities. However, we pledge for a flowing dialogue between anthropology and occupational therapy, especially in the Global South, where the discipline has been implemented as part of the neoliberal project. Indeed, as we argue in the following section, if we are able to go beyond a superficial use of "culture" - that can mislead us towards culturalist explanations- we can promote a debate over epistemological uses of his concept.

\section{Moving towards an epistemological reflection of culture within Occupational \\ Therapy}

We have previously discussed that culture as a concept has had little consensus in both anthropology and occupational therapy. On the contrary, it has long been a site of debate and contestation. Within mainstream occupational therapy, definitions of culture and diversity have certainly been profitable for the field and have been aimed to develop a multi-cultural practice, in which the lines between the Global North and Global South mark living conditions, health problems, socio-economic inequalities, etc. However, we will argue that, if we pass through certain usages of culture - such as those who allow culturalist explanations - and by pushing the discussion even further, we could establish an epistemological use of the notions of culture and diversity within occupational therapy.

Even if definitions of culture have been useful within the occupational therapy practice, we argue that the uses of these concepts should be rooted within the epistemology of the field. How can the concept of culture shape the field well beyond a better practice of therapy?

Beyond establishing a team of cultural competence or transcultural competence we suggest that mainstream 
occupational therapy could debate the concept of culture from within its founding ideas. Within mainstream occupational therapy it has been argued that with globalization and information era, professionals have become increasingly aware of the importance of discussing culture and diversity. This means that with the encounter of "the other" - traditionally placed in distant geographical lands- this reflection becomes relevant to think about.

The concept of culture instead of being used to explain difference (of populations and practices) could be integrated as a core principle of diversity that would be historically and politically situated. It is noteworthy that the discussions of these concepts have been sustained in the Global North viewing the issue of culture from a necessity of globalization. It is by the contrast of "the other" that this need to integrate the discussion became relevant. Migrant and minority populations have been mostly dealt in the Global North. But some of the so-called minority groups are in fact majority groups, for instance black and brown populations in Brazil or indigenous in Guatemala.

We have seen that economic and political ideas, especially capitalism and neoliberalism, had a strong imprint in the development of some of the founding ideas of mainstream occupational therapy. Even if occupational therapy has long been influenced by the biomedical/health fields, more recent shift towards humanities and social sciences has stimulated the debate over other levels of analysis that have entered the occupational therapy theoretical agenda (IWAMA, 2003). Also, a permanent reflections from the Global South can challenge and propose new meanings (MALFITANO et al., 2014).

\section{Conclusion}

In this essay we take a step back looking at some of the conceptualizations of "culture" in occupational therapy that have derived from anthropological thought. The following question remains to be further analyzed and discussed: To what extent could we discuss culture within the epistemological foundation of occupational therapy?

We mentioned that we would avoid any quick solutions or propositions to the question discussed. Indeed, as this essay has sought to demonstrate, it is precisely the discussion that proves to be fruitful. Well beyond the search for consensus, it is the always-drifting dialogue that merits reflection. Thus, this essay is a small contribution based on this belief.

\section{References}

BIEHL, J.; GOOD, B. J.; KLEINMAN, A. Subjectivity: ethnographic investigations. Berkeley: University of California Press, 2007.

BOURDIEU, P. The forms of capital. In: RICHARDSON, J. (Ed.). Handbook of theory and research for the sociology of education. New York: Greenwood, 1986. p. 241-258.

FARMER, P. On suffering and structural violence: a view from below. Daedalus, New York, v. 125, n. 12, p. 261-283, 1996.

FASSIN, D. Quand les corps se souviennent: expériences et politiques du sida en Afrique Du Sud. Paris: Editions La Découverte, 2006.

FITZGERALD, M. H. A dialogue on occupational therapy, culture, and families. The American Journal of Occupational Therapy, Bethesda, v. 58, n. 5, p. 489498, 2004.

FOUCAULT, M. The birth of biopolitics: lectures at the Collège de France, 1978-1979. New York: Picador, 2010.

FRANK, G.; BAUM, C.; LAW, M. Chronic conditions, health, and well-being in global contexts: occupational therapy in conversation with critical medical anthropology. In: MANDERSON, L.; SMITH-MORRIS, C. (Ed.). Chronic conditions, fluid states: chronicity and the anthropology of illness. New Brunswick: Rutgers University Press, 2010. p. 230-246.

FRANK, G.; BLOCK, P.; ZEMKE, R. Anthropology, Occupational Therapy and disability studies: collaborations and prospects. Practicing Anthropology, Oklahoma, v. 30, n. 3, p. 2-5, 2008.

FRANK, G.; ZEMKE, R. Occupational therapy foundations for political engagement and social transformation. In: POLLARD, N.; SAKELLARIOU, D.; KRONENBERG, F. A political practice of Occupational Therapy. Edinburgh: Elsevier Science, 2008. p. 111136.

GALHEIGO, S. M. Terapia ocupacional: a produção do conhecimento e o cotidiano da pratica sob o poder disciplinar em busca de um depoimento coletivo. 1988. 84 f. Dissertação (Mestrado em Educação) - Universidade Estadual de Campinas, Campinas, 1988.

GUSFIELD, J. R. Contested meanings: the construction of alcohol problems. Madison: University of Winconsin Press, 1996.

HELMAN, C. G. Culture health and illness. New York: Oxford University Press, 2007.

IWAMA, M. Toward culturally relevant epistemologies in Occupational Therapy. The American Journal of Oc- 
cupational Therapy, Bethesda, v. 57, n. 5, p. 582-588, 2003.

KINÉBANIAN, N.; STOMPH, M. Diversity matters: guiding principles on diversity and culture. World Federation of Occupational Therapists Bulletin, Forrestfield, v. 61, n. 1, p. 5-13, 2010.

MALFITANO, A. P. et al. Social occupational therapy: conversations about a brazilian experience. Canadian Journal of Occupational Therapy, Ottawa, v. 81, n. 5, p. 298-307, 2014
TRENTHAM, B. et al. Diversity and Inclusion within an Occupational Therapy curriculum. Australian Occupational Therapy Journal, Malden, v. 54, p. 49-56, 2007.

TYLOR, E. B. Primitive culture. London: John Murray, 1871 .

WATSON, R. Being before doing: the cultural identity (essence) of Occupational Therapy. Australian Occupational Therapy Journal, Malden, v. 53, n. 3, p. 151-158, 2006.

\section{Author's Contributions}

VS and SLS equally contributed drafting the article and revising it's content. They both approved the final version to be published.

\section{Notes}

${ }^{1}$ Global North and Global South are terms that we use in order to point towards regional parts of the world associated with standard of living, industrialization development, etc. However they are terms that are used to elucidate a geographic and societal divide, with exceptions, such as Australia and New Zeeland, which is considered a 'developed' country even if it is located in the southern hemisphere. 